УДК 811.111 '27 + 81'42

DOI https://doi.org/10.26661/2414-9594-2021-1-18

\title{
РЕПРЕЗЕНТАЦІЯ СТЕРЕОТИПУ АМЕРИКАНЦЯ АЗІАТСЬКОГО ПОХОДЖЕННЯ В МЕДІАДИСКУРСІ ХХ СТОЛІТТЯ
}

\author{
Любимова С. А. \\ кандидат філологічних наук, дочент, науковий співробітник, \\ докторант кафедри англійської філології, перекладу і філософії мови \\ імені О. О. Мороховського \\ Київський національний лінгвістичний університет \\ вул. Велика Васильківська, 73, Київ, Украӥна \\ orcid.org/0000-0001-7102-370X \\ elurus2006@gmail.com
}

\section{Ключові слова:}

стереотипізація, номінативні

одиниці, ідіома, оиянні

характеристики, медійна

риторика.
Комунікація представників різних культур та конфесій зумовлює виникнення етнічних стереотипів, які $\epsilon$ соціокультурними зразками груп певної раси чи національності, що формуються на основі оцінного сприйняття характерних відмінностей меншини від панівної більшості. Стереотипізація є соціальною категоризацією, яка відбувається за участю мовних засобів, які закріплюють стереотипи в колективній свідомості. Мовне оприявлення стереотипів відбувається за допомогою лексичних та ідіоматичних одиниць, стилістичних тариторичних засобів медіадискурсу. У статті висвітлюються результати дискурсивного аналізу мовних засобів репрезентації етнічного стереотипу американця азіатського походження в американському медіадискурсі XX століття. Цей етнічний стереотип реалізується в оціночних характеристиках зовнішньої та культурної відмінності меншини від домінантної етнічної групи. Формування стереотипу американця азіатського походження відбувалось у 20-ті роки XX століття 3 появою у країні перших китайських іммігрантів. За часи каліфорнійської золотої лихоманки до Сполучених Штатів заїжджають значна кількість робітників із Китаю, які видобували золото та виконували важку роботу. Американізація китайських іммігрантів зображається в медіадискурсі як шлях до успіху, але цей успіх сприймається як конкуренція. Зумовлене економічними чинниками змагання за робочі місця відобразилось у зневажливих назвах переселенців. Лексичні одиниці, які позначають цей стереотип, указують на негативне сприйняття етнічної меншини, що в медійному дискурсі відповідає риторичним прийомам, спрямованим на переконання в небезпечному характері іммігрантів з Азії. Відмінність зовнішнього вигляду і поведінки викликає непорозуміння і веде до ворожого сприйняття цієї расової групи. Рух за громадські права у 60-70-их роках XX століття змінює соціальнополітичну ситуацію у країні. Відтоді політична коректність визнається принципом співіснування різних расових, релігійних, культурних та інших груп, що значно зменшує прояви мовленнєвої нетолерантності в американському суспільстві. Визнання працьовитості та наполегливості американців азіатського походження, які працюють у торгівлі та науці, впливає на виникнення позитивного стереотипу наприкінці ХХ століття. 


\title{
STEREOTYPING OF ASIAN AMERICANS IN THE 20TH CENTURY MEDIA DISCOURSE
}

\author{
Lyubymova S. A. \\ Candidate of Philological Sciences, Associate Professor, Researcher, \\ Doctoral Student at the Department of English Philology, Translation and Philosophy of Language \\ named after O. O. Morokhovskyi \\ Kyiv National Linguistic University \\ Velyka Vasylkivska str., 73, Kyiv, Ukraine \\ orcid.org/0000-0001-7102-370X \\ elurus2006@gmail.com
}

Key words: stereotyping, nominative units, idiom, evaluation characteristics, media rhetoric.

\begin{abstract}
Stereotyping is the process of formation, fixation and dissemination of stereotypes in the media discourse. Based on mental operations of detecting differences from domineering majority, ethnic groups' stereotyping makes culture discrepancies prominent. Negative attitude is caused by misinterpretation of alien traditions, fixed in pejorative designations of ethnic groups. This article is devoted to the analysis of language means that portray Asian Americans' stereotype in media discourse of the 20th century. The description of this ethnic minority is based on external and cultural differences from the dominant group that caused negative attitude, reflected in ethnic slurs, such as Chink or Yellow Peril. The competition for jobs with white Americans in the beginning of the 20th century caused formation of a negative stereotype of Asian Americans. Media rhetorics of this period is aimed at conviction in dangerous nature of immigrants from Asia. They are described as bloodthirsty and monster-visaged Asian immigrants threatening the United States. Americanization of immigrants from Asia is depicted in media discourse as proud achievement that gives opportunity to realize dreams of success. From rags-to-riches stories are aimed to inspire immigrants from Asia to pursue their goals to become authentic Americans, which means to acquire American lifestyle. Political correctness of the 60's and the 70's of the previous century has had a significant impact on attitudes toward the ethnic minority, which is reflected in noticeable reduction of intolerance manifested in media discourse. The changes are reflected in the correction of geographical names. Attributed to people from Asia industry and persistence influenced the formation of positive stereotype of "a model minority" in the late 20th century. The considered examples show that designation of Asian Americans' stereotype in a metaphorical or metonymic way is based on their external properties, such as appearance and speech. The changes in media representation of the stereotype were conditioned by sociopolitical processes of the 20th century.
\end{abstract}

Постановка проблеми. Етнічні стереотипи неминуче виникають у багатонаціональній країні в результаті комунікації різних рас та етнічних груп. На їхньому підгрунті формуються інші соціокультурні стереотипи. До таких належать регіональні стереотипи, соціокультурні типажі й інші, реалізація яких забезпечується різнорівневими мовними засобами. Дослідження дискурсивної репрезентації розгалуженої системи соціокультурних стереотипів, які впливають на міжетнічні відносини у країні, визначає актуальність аналізу мовних засобів стереотипізації етнічних груп.
Як раціональні форми свідомості стереотипи допомагають осмислити фізичний світ [5], створюють внутрішньо однорідний розумовий простір. Вони з'являються у процесі соціальної категоризації - когнітивного процесу, який завершується мовним означуванням. Дослідники визначають співвіднесення стереотипів зі змістовною стороною мови і національною культурою. Їх номінація відбиває зв'язок між мовним знаком, що позначає фрагмент навколишнього середовища, 3 культурним досвідом, цінностями та нормами соціуму. Зберігання та поширення стереотипів у соціумі відбувається у процесі спілкування відповідно до 
семантичних принципів певної лінгвокультури [4, с. 134].

Мовне оприявлення стереотипів відбувається у висловлюваннях, які є відображенням так званих «розхожих істин» [2, с. 177], в анекдотах, пареміях, дериваціях, конотаціях і внутрішній формі етнонімів [1]. У формі фіксованих словосполучень вони породжуються на перетині узусу та мовної системи, характеризують стиль життя окремої соціальної групи. Дослідження мовного оприявлення стереотипів зосереджуються на окремих аспектах, які виявляються залежно від соціокультурного контексту їх реалізації [8, с. 66-69]. Це пояснюється складністю лінгвокогнітивної природи стереотипів.

У соціолінгвістичному трактуванні [8, с. 13] наголошується залежність мовного вираження стереотипу від світогляду мовної спільноти, яка виділяє ті чи інші якості певної групи і створює конвенційно-оцінний образ, що виступає зразком, 3 яким порівнюється нова інформація про соціальні угруповання.

У парадигмі когнітивної лінгвістики інтерпретація мовних структур та відтворення їх у текстах розглядаються у зв'язку з перцептивними й ментальними образами [3, с. 26]. Лінгвокогнітивні дослідження стереотипів спрямовані на опис встановленого в культурі та лінгвістично закріпленого знання, механізмів його категоризації й оцінювання, з урахуванням екстралінгвістичної інформації про традиції й уявлення народу [6, с. 67].

Етнолінгвістичні розвідки довели складність та багатогранність стереотипів, їхню відносність, помірну змінюваність та сприйнятливість до ідеологічного профілювання [7, с. 125]. Стереотипи етнічних груп відображають спрощене знання про особливості зовнішності, поведінку і моральні якості представників певної національної культури в порівнянні з домінантної етнічною групою. Існування деяких властивостей і ознак іноді необгрунтовано надається чи заперечується [10, с. 28]. Опис етнічного стереотипу складається 3 набору дескрипторів, що зображують візуальні й етичні характеристики [9, с. 2].

Мета статті полягає в описі мовних засобів репрезентації етнічного стереотипу американця азіатського походження в американському медіадискурсі XX ст.

Виклад основного матеріалу дослідження. Стереотипи виникають у певному культурно-історичному контексті, на тлі якого відбувається профілювання ознак, що зумовлюють стереотипізацію - процес формування, закріплення i поширення стереотипів у медійному просторі. Стереотип американця азіатського походження 3'являється у 20-ті pp. XIX ст. 3 появою перших китайських іммігрантів у країні. За часи каліфорнійської золотої лихоманки до країни заїжджає значна кількість робітників із Китаю, які видобували золото та виконували важку роботу. У НьюЙорку та Сан-Франциско (for years and years San Fransisco is the center of Chinese life) [21], Чикаго й інших містах появляються райони китайських магазинів та ресторанів, які називають китайськими кварталами (Chinatown). Вони стають не тільки соціальними центрами китайської громади, а й місцем розташування картярських домів (gambling) та локацією, де воюють члени китайської таємної організації, пов'язаної з організованою злочинністю (tong wars) [24].

У період економічної кризи 70-х рр. XIX ст. європейські іммігранти та місцеві жителі почали конкурентну боротьбу за робочі місця, що традиційно займали китайці. Зумовлена економічною конкуренцією неприязнь до китайців відобразилась у зневажливій назві стереотипу переселенців із Китаю - Chink, що було зафіксовано в 1878 p. Внутрішня форма слова Chink, його варіантів Chinkie та Chinky була зумовлена ввічливістю - рисою, яку атрибують китайцям. Фонетична інтерпретація ching-ching [18, c. 146] мовлення китайців передає слово Chink.

3 метою припинення масової імміграції китайців на захід країни у 1882 р. було ухвалено Закон (Chinese Exclusion Act), дія якого руйнувала «американську мрію» багатьох іммігрантів. Суспільне становище китайського населення відобразилось в ідіомі Chinaman's chance, скорочено Chinaman's, яку було зафіксовано в 1911 р. у значенні «відсутність удачі чи відсутність реальних шансів узагалі» [18, с. 145].

На початку ХХ ст. в медіадискурсі з'являються повідомлення про зіткнення білих американців iз китайськими працівниками (the Chinese Chink) на підгрунті конкуренції за робочі місця (collision with the Chink) [11]. Фpaza the Chinese Chink $\epsilon$ плеоназмом, у якому дублюється ознака «китайський», що підкреслює етнічну характеристику тих, кого вважають простодушними (harmless Chinese) [24] та цінними робітниками (rendering valuable services) [15].

Незважаючи на закон про заборону китайської імміграції, переселенці 3 Китаю незаконним шляхом (smuggling) потрапляють до країни (These Chinese are determined to come here and they are working with all the power to enter) [21]. Повні рішимості (determined to come), вони докладають значних зусиль, щоби в'їхати до країни їхньої мрії (they are working with all the power to enter). Але навіть у другому поколінні американці китайського походження сприймаються як іммігранти (the modern Chinese insist their children are Americans) [19]. Діти китайських іммігрантів, що були народжені в Америці, здобувають освіту в державних школах (These young men and women educated in 
American public schools) і у престижних університетах (Chinese students from Columbia University) [24]. Молоде покоління стає сприйнятливим до нових ідей (made them susceptible to the new ideas) і має великий вплив на китайську громаду у справі американізації та вдосконаленні відповідно до сучасних вимог суспільства (a tremendous influence for the Americanization and modernization of the yellow colony) [24]. Епітет «жовта» у фразі yellow colony підкреслює різницю між білими американцями та переселенцями з Китаю, від яких очікувалось прийняття американських цінностей та культури.

Американізація китайських іммігрантів зображається в медіадискурсі як шлях до успіху: First American Citizen of Chinese ancestry will take his place as a territorial legislator $\langle\ldots\rangle$, who began life as a bootblack on the streets, "I desired to carry out in some greater and more responsible manner, my duty as an American citizen", adding, he is proud to be a citizen of United states [16]. Той, кого називають американським громадянином китайського походження (American Citizen of Chinese ancestry), відчуває гордість за своє американське громадянство (proud to be a citizen of United states). Починаючи як вуличний чистильник чобіт (a bootblack on the streets), він стає членом місцевого законодавчого органу (a territorial legislator). Успішних американців китайського походження, які працюють у торгівлі та науці, уважають кращими представниками китайської спільноти (superior Chinks - better class merchants and scholars) [19]. Їхній успіх пов'язують із розумністю (the Chinese is always cuter), хитрістю (A wily bird is the chink) та самовладанням (poker faces) [19].

Американізація не може нівелювати китайську культуру тих, хто стає громадянами Америки: you may veneer a chanaman with mission varnish, cut off his queue, slave the slant off his eyebrows and even induce him to use a knife and fork, but the minute there's an emergency this willy bird sheds his camouflage and becomes - just an inscrutable Chink [19]. Процес асиміляції в цьому уривку зображується метафорично як маскування через нанесення блиску, що порівнюється з навертанням іновірців у християнство (veneer a chanaman with mission varnish). Асиміляція спрямована як на зникнення зовнішніх відмінностей китайців, що носять косу (cut off his queue) та зачісують брові (slave the slant off his eyebrows), так і побутових звичок китайців, що їдять за допомогою паличок (even induce him to use a knife and fork). Але, як визнає автор статті, попри маскування (camouflage), що дає можливість цим людям злитися з американським оточенням, вони залишаються загадковими і незрозумілими чужинцями (an inscrutable Chink).

Стереотипізація в медіадискурсі початку XX ст. категорії американців японського походження відбувається через зображення їх як серйозної та безпосередньої небезпеки для Сполучених Штатів, яка йде від «жовтої» раси (Yellow Peril). Автором ідіоми вважається германський імператор Вільгельм II, а в американський медіадискурс ідіома Yellow Peril потрапляє завдяки, як іронічно зауважується у статті, «доброзичливій турботі» медіамагната В. Херста (thanks to "benevolent care of Mr. Hearst") [18]. У «жовтій пресі», до розряду якої належала і газеті В. Херста New York Morning Journal, створювався образ кровожерливих (bloodthirsty) японців із вузькими очима (obliqueeyed) та нелюдським виразом обличчя (monstervisaged) [18]. Японців уважають найбільш розважливою і практичною нацією торговців у світі (There is no more shrewd "nation of shop-keepers" in the world than the Japanese), що робить їх потенційно небезпечними для американців (the act of threatening the United States) [18].

Зміни в медійній репрезентації стереотипу американців азіатського походження не відбуваються протягом десятиліть. Їх зображують озброєними та небезпечними для білих американців (Yellow Peril in which the yellow races were portrayed as arraying themselves against whites. Riverhead County Review) [22]. Обстріл Тихоокеанського флоту Військово-морських сил США японськими авіаносцями в 1941 р. підсилює негативний стереотип американців японського походження, що позначено ідіомою Yellow Peril. За часи Другої світової війни багато японців були переміщені із західного узбережжя Сполучених Штатів у концентраційні табори, що пояснювалось необхідністю відмежування нелояльних елементів від патріотично налаштованих американських громадян японського походження (Japanese American minority the American war effort to segregate disloyal elements from the loyal, patriotic Americans from Japanese descent) [17].

За часи війни у В'єтнамі в медіадискурсі знов актуалізується стереотип загрози (The Yellow Peril is back), що надходить від азіатської меншини (an authentic Yellow Peril with all-time favorite, the Huns, as people you love to hate) [13]. Справжня (authentic) небезпека йде від варварів (Huns), якими вважають людей азіатського походження. Оксюморон people you love to hate виражає суперечність між справжньою загрозою азіатської меншини та ii стереотипним уявленням. Ставлення до незрозумілої загрози вирішується ненавистю до цих людей, що дає можливість спокійно спати американцям, як іронічно описує автор статті: We can sleep a little better nights for knowing there's someone to hate [13].

Зміни у ставленні до етнічних меншин, що відбувались у суспільній свідомості в 70-х рр. XX ст., відображуються у виправленні географічних 
назв, де використовувались образливі позначення етнічних стереотипів: Jap Creek was changed to Japanese Creek, Chink Gulch to Chinese Gulch [20]. Зневажливе Jap, що є скороченням від Japanese, замінюється на повну форму (Japanese Creek), нейтральне Chinese уживається замість Chink у назві гірської ущелини (Chink Gulch).

Наприкінці XX ст. слово Chink спричиняє роздратування i протести в будь-якому вживанні, навіть як звична назва шкільної спортивної команди (Chinese-American organization protesting use of the official nickname "Chink" for its high school athletic teams) [14]. Це слово визиває люте обурення (flamed with indignation last night over a claim that Kearney used the phrase "goddammed Chinks") у тихих, стриманих і терплячих (usually a quiet, reserved, patient) американців азіатського походження [23]. Слово Chink зникає з узусу медіадискурсу наприкінці XX ст.

Висновки. Отже, комунікація представників різних культур та конфесій зумовлює виникнення стереотипів, які виявляються в лексико-семантичних та риторичних засобах медіадискурсу. Стере- отипізація американців, що мають азіатське походження, у медіадискурсі відбувається на основі увиразнення чужинних для панівної більшості ознак. Відмінність зовнішнього вигляду і поведінки викликає настороженість та тривогу, що веде до ворожого сприйняття цієї расової групи, як наслідок, появу негативного стереотипу американців азіатського походження.

Як результат боротьби за громадські права у 60-70-тих рр. ХХ ст. політична коректність стає принципом співіснування різних расових, релігійних, культурних та інших груп. Зміна ставлення до етнічних меншин значно зменшуе прояви мовленнєвої нетолерантності в американському суспільстві. Визнання працьовитості та наполегливості американців азіатського походження, які працюють у торгівлі та науці, впливає на виникнення позитивного стереотипу наприкінці XX ст. Перспективним у подальших розвідках етнічних стереотипів убачається дослідження змін медійної репрезентації інших расових та етнічних меншин американської лінгвокультури, порівняння їхньої динаміки в різних видах дискурсу.

\section{ЛІТЕРАТУРА}

1. Кашкин В.Б. Этнонимы и территория национальной души. Русское и финское коммуникативное поведение. Воронеж : Изд-во ВГТУ, 2000. Вып. 1. С. 62-70.

2. Кубрякова Е.С. Краткий словарь когнитивных терминов. Москва, 1997. 245 с.

3. Рубанець О.М. Особливості впливу когнітивних ідей на сучасний розвиток науки. Філософські проблеми гуманітарних наук : альманах. 2018. № 1 (27). С. 24-27.

4. Сорокин Ю.А. Стереотип, штамп, клише: к проблеме определения понятий. Общзение : теоретические и практические проблемы. 1978. С. 133-138.

5. Amodio D.M. The Neuroscience of Prejudice and Stereotyping. Nature reviews Neuroscience. 2014. P. 670.

6. Bartmińsksi J. Aspects of Cognitive Etnolinguistics / J. Zinken (Ed.). Shefield and Oakville : Equinox, 2009. 256 p.

7. Bartmiński J. What Does It Mean for Stereotypes to "Reside in Language"? Stereotypes and Linguistic Prejudices in Europe / A. Dąbrowska, W. Pisarek, G. Stickel (Eds.). Research Institute for Linguistics Hungarian Academy of Sciences, 2017. P. 115-135.

8. Coulmas F. Routineim Gesprach. Zurpragmatishen Fundirung der Idiomatik. Wiesbaden : Athenaion, 1981. $262 \mathrm{~S}$.

9. Lyubymova S. Stereotyping Indigeneity: the Case of Native American. Rupkatha Journal on Interdisciplinary Studies in Humanities. 2019. Vol. 11. № 2. DOI: 10.21659/rupkatha.v11n2.05.

10. Quasthoff M.U. The Uses of Stereotype in Everyday Argument : Theoretical and Empirical Aspects. Journal of Pragmatics. North-Holland Publishing Company, 1978. Vol. 2. Iss. 1. P. 1-48.

\section{ДЖЕРЕЛА ІЛЮСТРАТИВНОГО МАТЕРІАЛУ}

11. The Alexandria Times-Tribune. 1906. Editorial The Alexandria Times-Tribune. 15 September, 1906. URL: https://www.newspapers.com/image/80551791/?terms=chinese\%20chinks\&match.

12. Getlein F. Yellow Peril Turns up as Hate Target. Press Telegram. Long Beach, California. December 29 , 1965. URL: https://newspaperarchive.com/press-telegram-dec-29-1965-p-24/.

13. Hughes T.L. Chinese Protest "Chink" Nickname. Lubbock Avalanche-Journal. 1974, September 2. URL: https:/www.newspapers.com/image/61666463/.

14. Kearney County Advocate. Grateful to Chinese Kearney County Advocate. April $29,1921$. URL: https://www.newspapers.com/image/422274470.

15. Lincoln News Messenger. First Chinese American Citizen. 1926, December 3. URL: https://www.newspapers.com/image/474209354. 
16. The Minidoka Irrigator. A Blow of Racial Hysteria. The Minidoka Irrigator. 1943, July 31. URL: https://www.loc.gov/resource/sn84024049/1943-07-31/.

17. "Yellow Peril"? Fathered by Wilhelm, Nursed by Hearst. New York Tribune Review. 1918, March 24. URL: https://www.loc.gov/resource/2004540423/.

18. The New Partridge Dictionary of Slang and Unconventional English / T. Dalzell, T. Victor (Eds.). Routledge, 2018.

19. Pegler A.J. Chainatown's Reform are Depressingly Real. New-York Tribune. 1922, October 1. URL: https://www.loc.gov/resource/sn83030214/1922-10-01/.

20. Pomona Progress Bulletin. Here's How you Can Put New Name on the Map. Pomona Progress Bulletin. 1976, September 26. URL: https://newspaperarchive.com/pomona-progress-bulletin-sep-26-1976-p-34/.

21. Portsmouth Herald. Enourmous Profit at Enormous Risk. Portsmouth Herald. 1930, February 7. URL:https://newspaperarchive.com/portsmouth-herald-feb-07-1930/.

22. Old Folks Corner. Riverhead County Review. 1932. December 15. URL: https://newspaperarchive.com/ riverhead-county-review-dec-15-1932-p.

23. Kearney is Sweated over "Chinks" Remark. The San Francisco Examiner. 1979. № 27. URL: https://www.newspapers.com/image/460726415/.

24. New York's China Town Annexed to the United States. The Sun. 1914, February 8. URL: https://www.loc.gov/item/sn78004456/1914-02-08/.

\section{REFERENCES}

1. Kashkin, V.B. (2000). Etnonimyi i territoriya natsionalnoy dushi. Russkoe i finskoe kommunikativnoe povedenie [Ethnonyms and the territory of the national soul. Russian and Finnish communicative behavior] Voronezh: Izd-vo VGTU, Vyip. 1.

2. Kubryakova, E.S. (1997). Kratkiy slovar kognitivnyih terminov [Brief Dictionary of Cognitive Terms]. Moskva: Filol. f-t MGU im. M.V. Lomonosova.

3. Rubanets, O.M. (2018). Osoblivosti vplivu kognitivnih idey na suchasniy rozvitok nauki [Specifics of influence of cognitive ideas to modern development of science]. Almanah. FIlosofski problemi gumanitarnih nauk. № 1 (27). 24-27.

4. Sorokin, Yu.A. (1978). Stereotip, shtamp, klishe: k probleme opredeleniya ponyatiy. [Stereotype, stamp, cliché: to the problem of determining concepts]. Obschenie: teoreticheskie i prakticheskie problemy, $133-138$.

5. Amodio, D.M. (2014). The Neuroscience of Prejudice and Stereotyping. Nature reviews Neuroscience, P. 670-6.

6. Bartmińsksi, J. (2009). Aspects of Cognitive Etnolinguistics. Shefield and Oakville: Equinox.

7. Bartmiński, J. (2017). What Does It Mean for Stereotypes to "Reside in Language"? Stereotypes and Linguistic Prejudices in Europe. Research Institute for Linguistics Hungarian Academy of Sciences, 115-135.

8. Coulmas, F. (1981). Routineim Gesprach. Zurpragmatishen Fundirung der Idiomatik. Wiesbaden : Athenaion.

9. Lyubymova, S. (2019). Stereotyping Indigeneity: the Case of Native American. Rupkatha Journal on Interdisciplinary Studies in Humanities, 11 (2) DOI: 10.21659/rupkatha.v11n2.05.

10. Quasthoff, M.U. (1978). The Uses of Stereotype in Everyday Argument: Theoretical and Empirical Aspects. Journal of Pragmatics, 2, (1). North-Holland Publishing Company, 1-48.

\section{SOURCES OF ILLUSTRATIVE MATERIAL}

11. The Alexandria Times-Tribune (1906). Editorial The Alexandria Times-Tribune 15 September, 1906. URL: https://www.newspapers.com/image/80551791/?terms=chinese\%20chinks\&match

12. Getlein, F. (1965). Yellow Peril Turns up as Hate Target. Press Telegram, Long Beach, California, December 29, 1965. URL: https://newspaperarchive.com/press-telegram-dec-29-1965-p-24/

13. Hughes, T.L. (1974). Chinese Protest "Chink" Nickname. Lubbock Avalanche-Journal, September 2, 1974. URL: https://www.newspapers.com/image/61666463/

14. Kearney County Advocate (1921). Grateful to Chinese Kearney County Advocate April 29, 1921. URL: https://www.newspapers.com/image/422274470

15. Lincoln News Messenger (1926). First Chinese American Citizen. December 3, 1926. URL: https://www.newspapers.com/image/474209354

16. The Minidoka Irrigator (1943). A Blow of Racial Hysteria. The Minidoka Irrigator, July 31, 1943. URL: https://www.loc.gov/resource/sn84024049/1943-07-31/ 
17. New York Tribune Review (1918). "Yellow Peril"? Fathered by Wilhelm, Nursed by Hearst. New York Tribune Review, March 24, 1918. URL: https://www.loc.gov/resource/2004540423/

18. The New Partridge Dictionary of Slang and Unconventional English (2018). (Eds.) T. Dalzell, T. Victor. Routledge.

19. Pegler, A.J. (1922). Chainatown's Reform are Depressingly Real. New-York Tribune, October 1, 1922. URL: https://www.loc.gov/resource/sn83030214/1922-10-01/

20. Pomona Progress Bulletin (1976). Here's How you Can Put New Name on the Map. Pomona Progress Bulletin, September 26, 1976. URL: https://newspaperarchive.com/pomona-progress-bulletinsep-26-1976-p-34/

21. Portsmouth Herald (1930). Enourmous Profit at Enormous Risk. Portsmouth Herald February 7, 1930. URL: https://newspaperarchive.com/portsmouth-herald-feb-07-1930/

22. Riverhead County Review (1932). Old Folks Corner. Riverhead County Review, December 15, 1932. URL: https://newspaperarchive.com/riverhead-county-review-dec-15-1932-p.

23. The San Francisco Examiner (1979). Kearney is Sweated over "Chinks" Remark. The San Francisco Examiner, 27, 1979. URL: https://www.newspapers.com/image/460726415/.

24. The Sun (1914). New York's China Town Annexed to the Unated States. The Sun, February 8, 1914. URL: https://www.loc.gov/item/sn78004456/1914-02-08/. 